\title{
Markers to Emigration from North West Sutherland: The Presbyterian Cemeteries of Lot 21 of Prince Edward Island
}

\author{
Malcolm Bangor-Jones
}

\section{check for}

updates

Citation: Bangor-Jones, Malcolm. 2021. Markers to Emigration from North West Sutherland: The Presbyterian Cemeteries of Lot 21 of Prince Edward Island. Genealogy 5: 35. https://doi.org/10.3390/ genealogy5020035

Received: 6 October 2020

Accepted: 11 March 2021

Published: 2 April 2021

Publisher's Note: MDPI stays neutra with regard to jurisdictional claims in published maps and institutional affiliations.

Copyright: (C) 2021 by the author. Licensee MDPI, Basel, Switzerland. This article is an open access article distributed under the terms and conditions of the Creative Commons Attribution (CC BY) license (https:/ / creativecommons.org/licenses/by/ $4.0 /)$.
Independent Researcher, Sutherland IV27 4LR, UK; mbangorjones@btinternet.com

\begin{abstract}
A number of studies of emigrant communities in Canada have utilized the evidence from gravemarkers to indicate place of origin. This investigation of gravemarkers from five Presbyterian cemeteries on Lot 21 of Prince Edward Island demonstrates emigration from an area of the north west Highlands of Scotland to a particular community over a period of approximately 50 years. The chronology of emigration as revealed in the gravemarkers is analysed in the light of what is known about tenurial change within the homeland. Emigrant histories of several individuals or families recorded in two of the cemeteries have been compiled to examine their family and communities in the homeland, to set out the circumstances under which they emigrated and to outline the challenges they faced in Canada. An examination of the evidence from gravemarkers alongside a study of extant surnames and family reconstitution suggests that, in this case, gravemarkers provide a valuable but only partial indication of precise origin.
\end{abstract}

Keywords: Scottish Highlands; gravemarkers; emigration; Prince Edward Island

\section{Introduction}

Lot 21 in Granville Parish of Prince Edward Island (PEI) had sufficient settlers from the county of Sutherland in the Scottish Highlands to allow it to be regarded today as one of several of what have been termed "transplanted Sutherland communities" in Canada (Hunter 2015, p. 321). There is an assumption in many quarters that people from the Highlands were compelled to leave, usually as a result of clearances carried out by landlords bent on raising estate revenues. On the other hand, some scholars have argued that emigration was more a matter of choice. This article analyses the information from gravemarkers and then provides a handful of emigrant histories to detail the chronology of emigration and the circumstances under which people left the north and west of Sutherland over a 50-year period.

\section{Literature Review \\ 2.1. Cemetery Studies}

A succinct review of cemetery studies has been provided by Stanley-Blackwell and Linkletter (Stanley-Blackwell and Linkletter 2018). Although ethnic or group identity has featured in a number of studies, place association has not been given a great deal of attention. Snell's study of belonging and local attachment in England and Wales over the period 1700 to 1950, in which gravemarkers were used as one form of evidence, is in many respects an outlier (an analysis of approximately 16,000 gravestones revealed a clear and consistent pattern with mention of place rising in the 19th century to peak in the period 1860 to 90 followed by a marked decline). Indeed, Snell considered that the use of gravemarkers as evidence for place association was a "completely untouched historical subject" (Snell 2009, p. 455). It is thus understandable that a recently published collection of essays on British and Irish grave memorials abroad advances a claim to be a pioneering study of memorialisation practices (Evans and McCarthy 2020). Most pertinently for this article, the collection includes a study by Stanley-Blackwell and Linkletter on the memorials to Scottish immigrants in Nova Scotia (Stanley-Blackwell and Linkletter 2020). 
That said, gravemarkers have been utilized in studies to analyse the origins of immigrant communities. As Campey notes, pride in Scottish roots appears to have extended to the grave and gravemarkers have proved a useful source of evidence (Campey 2001, p. 8). Little, for instance, in his study of emigrants from the Isle of Lewis in Scotland to Winslow Township in Quebec notes how gravemarkers provide evidence of place of origin. He also states how settlers identified with a certain district rather than with the township as a whole: each district had its own cemetery. With the decline of the Scottish population, the cemeteries are now "the last testimony to the Scots presence in this region" (Little 1991, p. 251). Hornsby utilised information from a survey of gravestones along with genealogies collected in 1922 for Inverness County to map source areas for Scottish emigrants to Cape Breton: the survey does not in fact cover all of Cape Breton but the map is particularly effective in showing emigration from parts of the West Highlands and Western Isles of Scotland (Hornsby 1988, p. 16). Campey used the publication of the PEI Genealogical Society containing both gravemarker inscriptions and death notices to identify the geography of Scottish settlement on PEI (Campey 2001, p. 61). In his study of the Irish settlers of Prince Edward Island, O'Grady notes how the tombstones in one Catholic cemetery refer to birthplaces in Tipperary, Kilkenny, Wexford and Waterford. He also describes the memorials to Irish settlers in Charlottetown (O'Grady 2004, pp. 111, 199-201).

\subsection{Emigration from the Scottish Highlands and the Settlement of PEI}

Emigration from Scotland is a central fact of Scottish demographic history: the extent of the outpouring of people from Scotland, particularly but not just during the 19th century, is often referred to as a diaspora (Harper 2003; Devine 2011). Emigration from the Scottish Highlands has an especially high profile given the association which is often made with the Highland Clearances. Emigration was a contentious issue at the time and has remained so since (Richards 1985). Central to the issue are questions, such as were Highlanders expelled from the region or were there other, more general causes at work? One viewpoint has been to downplay the element of compulsion. Bumsted has argued that prior to 1815, emigration from the Scottish Highlands was a matter of choice and that emigrants went against the wishes of their landlords. It is a view largely shared by McLean (Bumsted 1982; McLean 1991). Such a view inevitably contrasts with what certainly happened during and immediately following the Potato Famine when an expansion of emigration was achieved in not a few instances by coercion on the part of landlords (Devine 2011). More recently, Richards examined the case of the Scottish Highlands as one of a number of selected areas within Britain as a whole in a search for the conditions of change. Landlord expulsion is examined alongside the impact of population accumulation and economic re-structuring (Richards 2018).

From the perspective of the homeland, the historiography of emigration from Sutherland has tended to be dominated by the emigration of the 1770s and the remarkable story of the Rev Norman MacLeod from Assynt who settled in Cape Breton in 1820 but then, over 25 years later, led his community to New Zealand. In the pre-Clearance period, emigration from the Scottish Highlands in general has been seen as being led by the tacksmen or minor gentry. In the northern Highlands, however, examples of tacksmen emigrating prior to 1800 are very few. More to the point, tacksmen in Sutherland were taking an increasingly commercial approach to farming, were dominant in the cattle trade, and several were to engage in sheepfarming. During the 1770s, some tacksmen viewed organising emigration solely as a means of making money (Bangor-Jones 2000). Harper has published a broadscale study of emigration from Sutherland and Caithness over a longer time span which emphasizes the role of intermediaries and persuaders (Harper 2017).

In an account of the clearances on the Sutherland estate, which puts the experience of the dispossessed at its centre, Hunter draws attention to those who chose not to be resettled on the estate. He tells the story of the Red River settlement in Manitoba but more relevantly refers to areas in Nova Scotia which he describes as "transplanted Sutherland 
communities" (Hunter 2015, p. 321). However, less is currently known about the impact of the clearances on the Reay estate which, until it became part of the Sutherland estate in 1829 , occupied the north and west of the county. These clearances began in the early 1800 s and lasted into the 1820s. This prolonged process of clearance was further complicated by the fact that many former possessors were allowed to remain as subtenants on some sheepfarms for varying periods. While it is possible to obtain a good impression of the extent of the clearances, it is more difficult to gauge the balance between the number of families resettled on the estate and the number who chose to emigrate.

In the late 1820s and early 1830s, there was a burst of emigration from Sutherland as a whole which contained echoes of the early 1770s in that it was UK-wide. By the 1830s, the obvious pressure of people on land in the Scottish Highlands in general encouraged talk amongst landlords and estate managers of a "redundant population". Richards has examined emigration from north and west of Sutherland in the 1840s and early 1850s in a study which focuses on the evolving thinking by the landlord and his estate managers as to whether emigration could or should be a solution to congestion and destitution (Richards 2011). Targeted assistance was available from the early 1840s, but the onset of the potato disease in 1846 led to significant landlord expenditure on relief works and assisted emigration.

Turning to PEI as a destination, it is important to keep in view that the Scots became the largest ethnic group on the island and that PEI was to become the most Scottish province in Canada. Moreover, as Kennedy has suggested, over $80 \%$ of the Scots on PEI were from the Highlands and Islands of Scotland (Kennedy 2003, p. 31). There is, however, a shortage of detailed information on the numbers, chronology and background to these emigrations. Detailed passenger lists are rare and often difficult to analyse (Dale 1976, 1977a, 1977b).

Kennedy has traced the movement of people from the Highlands of Scotland to PEI from the late 1760s to the early 1860s with a particular emphasis on the Gaelic perspective (Kennedy 1995, 2003). Although most areas of the Highlands were represented in the emigration to PEI, the bulk of the emigrants were from five major areas: the Catholic Highlands; an area bounding the Sound of Raasay; Northern Argyll including Mull and Colonsay; Perthshire; and north west Sutherland (Kennedy 1995, pp. 4-5). Particular attention has focused on the history of the settlements established by the Earl of Selkirk (Bumsted 1978b, 1978c, 1979; Sheets 2004) and also the emigration of Catholic families from the Western Isles in the early 1770s led by MacDonald of Glenaladale (Bumsted 1978a, 1979).

Kennedy has devoted the most attention to the settlement of emigrants from Sutherland. He states that the emigration began in 1806 and identifies a series of subsequent phases (1815-1816, 1835, 1841-1842 and 1847-1848). He also draws attention to the localized nature of the settlement in Queens County around French River, New London and Granville. He states, however, that a lack of evidence makes the study of emigration from Sutherland to PEI particularly difficult (Kennedy 1995). Indeed, there is only one relevant passenger list (the list for the Elizabeth and Ann of 1806) and it does not group families nor mention place of residence (Dale 1977b). Furthermore, there is no reference to Sutherland or a likely port of embarkation for emigrants from Sutherland in the list of ships arriving in PEI compiled by Jones and Fraser $(1984,1985 a, 1985 b)$ and Fraser $(1989,1990)$. This lack of evidence may be partly explained by the fact that some of the Sutherland immigrants may well have travelled to PEI via Pictou or Miramichi. It is noteworthy that Campey's list of ships crossing from Scotland to PEI includes the Ellen, explaining that an unknown number of the 154 passengers who disembarked at Pictou in 1848 settled on PEI (Campey 2001, p. 149).

The history of settlement and landholding on Prince Edward Island (for a while until 1799 known as the Island of St. John) is distinctive when compared with other areas settled by Scottish Highlanders in Canada. The island had been surveyed and divided into 67 lots or townships (for a map see Bumsted 1987, p. xiii). In 1767, these were disposed of by the British government in a lottery to private proprietors who undertook to settle their lands. The lots were essentially estates of 20,000 acres. From a Scottish point of view, the term "lot" 
might be confusing in that it is typically used to denote a small area of land and was often employed as an alternative term to croft. The term township could be equally confusing in that townships in Canada are far larger than townships in the Scottish Highlands and more akin to parishes in size. The island was not populated as quickly as was intended by the government and a survey of 1799 revealed that a good number of lots had not been settled at all. There were, however, already emigrants from the Scottish Highlands on some lots (Adams and Somerville 1993, pp. 51-62, 69-71).

Lot 21 is located within Grenville parish and stretches inland from the north coast. The northern part of the Lot was attractive to settlers whereas the southern part, comprising South Granville and Pleasant Valley, was only settled later (Pleasant Valley History Committee 2019, p. 4). The early settlement, however, was unusual in that it was the setting for the attempt in the 1770s by English Quakers to found the town of New London intended to be based on fisheries and trade (Cousins 2016). The settlement did not succeed and the site was abandoned (the current community of New London is in a completely different location). Ownership of the Lot came into the hands of John Cambridge who had served as agent to the Quakers. Cambridge died in 1831 and the Lot was sold in 1838 to Samuel Cunard, the powerful merchant and shipping magnate from Nova Scotia. Cunard also acquired several other lots and became the largest proprietor on PEI.

A number of the earlier immigrants from Sutherland became freeholders. However, most of the Sutherland immigrants took up land as tenants. The leases granted by both Cambridge and Cunard were of a similar nature: they were usually improving leases granted for 999 years at 1 shilling per acre. Most leases granted by Cunard were for 50 or so acres, although there were a few of around 100 acres (RG15, Cunard Rent Book 1841-1851). It is not the purpose of this article to consider the controversy over the land question which raged on PEI for decades and how it related to Lot 21, other than to note that Cunard's trustees voluntarily sold his entire estate to the government in 1866. According to the township ledger, a considerable number of tenants on Lot 21 bought their lands that year.

\section{Discussion}

\subsection{An Overview of the Fieldwork Evidence}

The cemeteries investigated on PEI were those known to contain burials of Presbyterian Scots: Sim's Field and Yankee Hill, both at French River; Geddie Memorial Church Cemetery and New London Peoples Cemetery (formerly the New London Protestant Cemetery), both at New London; and the Presbyterian Church Cemetery at South Granville. The information provided by the gravemarkers comes in the first instance from the PEI Genealogical Society transcripts supplemented by the author's fieldwork (PEIGS 2000a, 2000b, 2000c, 2000d, 2011).

The transcriptions of the PEI Genealogical Society (PEIGS) are similar in nature to those published by the Scottish Genealogical Society, including the volume for Sutherland (Cowper and Ross 1989). High importance has been placed on what was considered to be essential information for family historians. Recent recording work in Scotland has adopted a more thorough and more holistic approach. This includes: the exact transcription of every word or abbreviation; locating and uncovering buried stones; a systematic approach to iconography; and the use of digital enhancement to reveal 'hidden' text or symbols on weathered stones.

Sim's Field is a simple circular cemetery surrounded by a low earth boundary wall and contains five headstones. The earliest headstone commemorates a death in 1816 and the cemetery is said to span the period from 1816 to 1843 (PEIGS 2000b). However, it should not be assumed that the 1816 headstone marks the establishment of the cemetery. There are a number of simple stone gravemarkers with no inscriptions which were considered by Cousins to mark the burials of members of the early Quakers of New London (Cousins 2016, p. 157). Support for his suggestion comes from the documents concerning a dispute over a right of way which led to the production of a report and map in 1811 . These documents referred to an "old Burying place" which had been "used by the Inhabitants 
until within these few Years" (Stewart 1983, p. 16). It would appear that the inscribed gravemarkers represent a period of re-use. There is also evidence that the cemetery has been remodeled in the past. The earliest headstone refers to the "mound" containing the remains of William Mackay and his wife but the cemetery is now quite flat. The transcript of the cemetery, which incorporates information gathered in 1939, also refers to the marks of two full-length graves and one short one. These graves, too, are no longer evident. Sim's Field Cemetery became overgrown but was cleared in 1971 and was declared a memorial during the Island's centennial year in 1973 (Stewart 1983). More recently, however, the simple stone gravemarkers with no inscriptions were uplifted and placed on concrete paving slabs. It is unfortunate that some of the significance of the site has been lost. See Figure 1a,b.

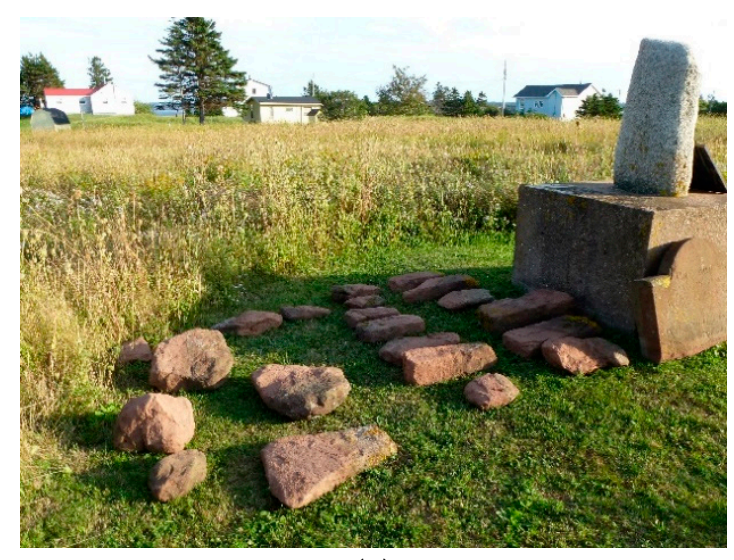

(a)

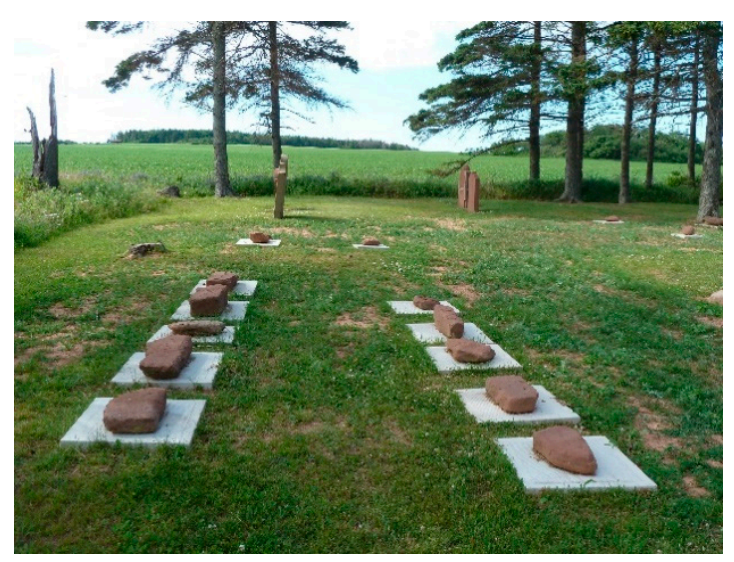

(b)

Figure 1. Gravemarkers at Sim's Field Cemetery: (a) 2016 and (b) 2017.

Yankee Hill Cemetery is another pioneer cemetery and was also declared a memorial in 1973. Although the earliest headstone is dated 1815, it is possible the cemetery was established in 1810 when a log church was built on the corner of the cemetery. Although cleared at the same time as Sim's Field, many of the 20 or so stones and the cemetery as a whole are now not in the best of condition. Interestingly, there are no gravemarkers for a number of burials which are supposed to have been made at the cemetery (PEIGS 2000a).

Geddie Memorial Church Cemetery (named after the Presbyterian minister, the Rev John Geddie), and New London Peoples Cemetery were established a little later and effectively replaced the two pioneer cemeteries. They are much larger cemeteries. The South Granville Cemetery is smaller: the Presbyterian church at South Granville was established in the mid-1860s to serve the local community, which been established at the southern end of Lot 21.

Almost all of the contemporary gravemarkers commemorating emigrants from Sutherland, either identified on the marker or known through family research, are headstones. Only one tablestone was found: that at Yankee Hill to John MacLeod of Durness who died in 1836. The earlier headstones tend to be sandstone and most have little more than a simple inscription. Later ones are predominantly in "white stone" - a dolomitic marble which is unfortunately not immune to weathering. A sizeable minority of later markers are four-sided pillars often topped by an urn.

The majority of gravemarkers are relatively plain with few or no symbols. The symbols which are found include: the willow tree, a symbol of mourning; hands, which might be either two clasped hands or a hand pointing upwards (on the gravemarker for William McKay at New London, the hand points to the words "God is Love"); and open books and curtains or drapes drawn back to provide a framing device. The markers examined appear to be too late in date to include the winged or angel heads found in Nova Scotia for gravemarkers of the period 1800-1830. Despite the number of natives of Scotland, no markers with the Scottish symbol of the thistle were found, also in contrast to Nova Scotia 
(Trask 1978, pp. 15, 26-27; Stanley-Blackwell and Linkletter 2020). The numbers of Gaelic speakers from Sutherland notwithstanding, gravemarkers with Gaelic inscriptions are non-existent-it is also the case that there are very few Gaelic inscriptions in Sutherland. It is worth pointing out in this connection that there are no surviving Gaelic place-names in Lot 21.

Epitaphs usually take the form of a short religious message placed either below the inscription or on the pages of an open book. For example: William Keir a native of Sutherlandshire buried at South Granville in 1914: "Life is not our own-'tis but a loan to be repaid;" and McKay Campbell, who emigrated from Durness in 1842 and was buried at New London in 1883: "His last words were Oh Lord give me a place with thyself." Campbell was from Durin of Durness and had married Mary Gunn from Achriesgill of Eddrachillis in 1829 (Lamb 2014).

Occasionally, lengthier tributes are found which can provide insight into the lives of the deceased or how they were intended to be remembered. The gravemarker at New London of Rodrick McLeod and his wife Cathrine McLeod, who both died in 1859, states that "They were both natives of the county of Sutherland and emigrated to this country 1847 they both unoffensively and exemplary to there end adhering to the scriptures of truth as their guid for time and futurity". The grammar and spelling are distinctive.

Not every person of exemplary conduct or of public faith had an epitaph. Hector Falconer served as an elder, conducted services in the absence of a minister, and was instrumental in establishing the South Granville Presbyterian Church in the 1860s (MacLennan). However, his gravemarker at South Granville merely notes the date of his death and his age.

The surviving gravemarkers only represent a portion of the larger population. It is very likely that gravemarkers have been lost or destroyed (some gravemarkers are clearly replacements). On the other hand, it is also the case that there may have been some people, particularly from households without means, who were buried without ever being commemorated by a gravemarker: they are thus anonymous.

There are similarities with the evidence from the north and west of Sutherland, where parishes were large and often had number of places of burial. For a cemetery such as that at Scourie on the west coast, the earliest visible gravemakers are late 18th- to early 19th-century headstones and almost all commemorate local tacksmen. It is apparent that the gravemarkers of the majority of the community - the small tenant population-are either non-existent or at best formed by a plain stone slab. In time, some such slabs were marked with initials using recognized abbreviations for surnames, for example, MK for Mackenzie. As the 19th century progressed, headstones and table stones became more common for the community as a whole. In passing, it may be remarked that there are no Gaelic inscriptions for the first half of the 19th century despite the people being more than $90 \%$ Gaelic-speaking (the relatively small number of Gaelic inscriptions belong to the late-19th- century Celtic Revival and are often associated with Celtic-style ornamented crosses).

A significant proportion of the gravemarkers of what were probably first-generation immigrants from Sutherland do not record their geographical origins. However, gravemarkers for "natives" of Sutherland were to be found in all of the five Presbyterian cemeteries in Lot 21: see Table 1:

Table 1. Numbers of gravemarkers in each cemetery with place of birth.

\begin{tabular}{ccc}
\hline Cemetery & Sutherland & Other Scottish \\
\hline Sim's Field & 1 & 0 \\
Yankee Hill & 5 & 0 \\
Geddie Memorial & 4 & 10 \\
New London & 20 & 11 \\
South Granville & 17 & 1 \\
\hline
\end{tabular}


Those buried in the Presbyterian cemeteries of Lot 21 were not all from Sutherland. In particular, the Geddie Memorial Cemetery includes gravemarkers for natives of Dumfriesshire, Peebles and Stirlingshire, while the New London Cemetery contains gravemarkers for natives of Dumfries, Skye, Stirlingshire and Perthshire. On the other hand, the Presbyterian community centred on South Granville appears, from the evidence of gravemarkers alone, to have been almost wholly from Sutherland. Family reconstruction would probably confirm this. It is important to bear in mind that "natives" of Sutherland also settled in adjoining lots, especially Lots 20 and 67.

Most of those who had immigrated from Sutherland stated that they were natives of "Sutherlandshire". Some, however, gave a more precise location in Sutherland. One was from the parish of Tongue and one from parish of West of Farr. A clear majority stated that they were natives of the parish of Durness. It should not be automatically assumed that all who were stated to be natives of Durness were born in that parish but most probably were. On the other hand, a study of the surnames and family reconstitution for some of the first-generation emigrants buried at New London and South Granville demonstrates that a good number were from the adjoining parish of Eddrachillis (this includes some of those stated to be natives of Sutherland and some with no stated place of nativity). For instance, of the various households from Handa Island in the parish of Eddrachillis, two who emigrated in 1847 were buried at New London while at least three who emigrated the following year were buried at South Granville.

Valuable information is also provided by those gravemarkers which state the year when the person emigrated: see Table 2.

Table 2. Year of Emigration for Natives of Sutherland.

\begin{tabular}{|c|c|c|c|}
\hline Cemetery & Parish & County & Emigrated \\
\hline Sim's Field & Tongue & - & 1806 \\
\hline Yankee Hill & Durness & - & 1806 \\
\hline Geddie Memorial & - & Sutherland & 1806 \\
\hline New London & - & Sutherland & 1815 \\
\hline New London & - & Sutherland & 1815 \\
\hline New London & Durness & Sutherland & 1815 \\
\hline New London & - & Sutherland & 1816 \\
\hline New London & - & Sutherland & 1831 \\
\hline New London & - & Sutherland & 1835 \\
\hline New London & - & Sutherland & 1835 \\
\hline South Granville & Durness & - & 1835 \\
\hline South Granville & & Sutherland & 1840 \\
\hline South Granville & & Sutherland & 1840 \\
\hline New London & & Sutherland & 1841 \\
\hline South Granville & & Sutherland & 1841 \\
\hline New London & Durness & Sutherland & 1842 \\
\hline New London & & Sutherland & 1847 \\
\hline New London & & Sutherland & 1847 \\
\hline New London & & Sutherland & 1847 \\
\hline South Granville & Durness & Sutherland & 1847 \\
\hline South Granville & & Sutherland & 1848 \\
\hline South Granville & & Sutherland & 1848 \\
\hline South Granville & & Sutherland & 1848 \\
\hline South Granville & & Sutherland & 1848 \\
\hline
\end{tabular}

The table provides clear evidence of the continuing attraction of PEI for emigrants from Sutherland. While the numbers of gravemarkers with dating evidence is small, the chronology clearly suggests a relationship between what is known about emigration and the timing of tenancy changes in the north west of Sutherland. The date of the earliest passenger ship in 1806 could well be significant given the drawn-out nature of the process of clearance on the Reay estate. Similarly, the years 1815 and 1816 would appear to coincide 
with further tenancy changes on that estate. The one individual who emigrated in 1831 suggests that the north west of Sutherland did not entirely escape the enthusiasm for emigration, which was certainly very marked in eastern Sutherland. Emigration thereafter continued with a significant number leaving the north west of Sutherland in the early 1840s. Those who came in 1847 and 1848 were almost certainly subsidized by the Duke of Sutherland. Some came from townships which were cleared (see the emigrant histories below). However, we can judge from various passenger lists compiled by the estate managers that emigrants from cleared townships were in a minority.

\subsection{Emigrant Histories: William Mackay and William Boyce Mackenzie, Sim's Field Cemetery}

One of the small number of headstones at Sim's Field Cemetery commemorates William Mackay and his wife Jane Scobie who are stated to have emigrated from Kirkiboll in the parish of Tongue in 1806. See Figure 2a. Kirkiboll, now essentially contained within the village of Tongue on the north coast of Sutherland, was then still part of Lord Reay's estate. William Mackay was the eldest son of John Mackay, a surgeon in Armadale in the parish of Farr, who later settled at Feulsaid to the south of Tongue. He was thus a descendant of Donald Balloch, first of the Mackays of Scourie and a son of Iye Du Mackay of Strathnaver, chief of the clan Mackay. In 1784, William Mackay had married Jane a daughter of Kenneth Scobie, tacksman of the farm of Achmore and others in Assynt and brother-in-law of George Mackay of Bighouse (Mackay 1906, pp. 286-87, 299, 331).

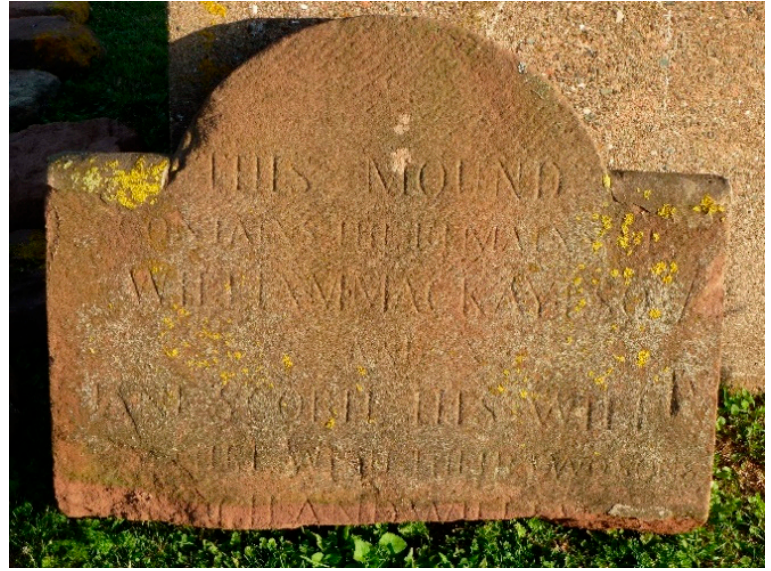

(a)

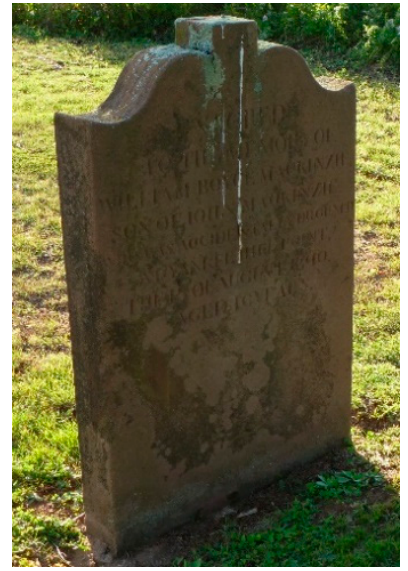

(b)

Figure 2. (a) Gravestone of William Mackay and Jane Scobie, Sim's Field Cemetery (2016); (b) gravestone of Boyce Mackenzie, Sim's Field Cemetery (2016).

In view of his father's association, William Mackay may have been the tenant of Feulsaid between 1789 and 1796 and possibly held other tenancies in the vicinity (Reay Papers, GD84/2/84). In 1797 William became tenant of the major portion of Kirkiboll and also of the inn or public house at Kirkiboll with the license to retail spirits along with some more distant grazings. He was due a total annual rent of almost $£ 14$, which contrasted with the average small tenant who paid a rent of from $£ 1$ to $£ 2$. The inn was in the vicinity of Lord Reay's seat at Tongue and was the public venue for the conducting of estate business, collecting of rents, and the holding of sheriff and other courts. This was a substantial holding and William's status was indicated by the use of the title "Mr" (Sutherland Papers, Dep.313/3326 Rental 1797; Dornoch Sheriff Court Records, SC9/7/). While not possessing a holding as sizeable as the leading tacksmen on the estate, William Mackay was a cut above the numerous small tenants.

He was, however, to suffer from the demand for higher rents from Lord Reay and the rearrangements which came in 1801 and following years. In January 1806, Donald Forbes, a tacksman who had taken one of the large sheepfarms and who had previously held the inn at Kirkiboll, had raised with Lord Reay the question of what was to become of William: 
"It is regretted Poor Wm Mckay in Kirkiboll gets no Holding with all his faults he was usefull among the Community \& has a heavy family." (Sutherland Papers, Dep.313/3369, Donald Forbes to Lord Reay, 15 January 1806). This approach appears to have been ignored and a month or so later Mackay and the other tenants of Kirkiboll were served with a summons of removal by the landlord. With no extant lease, William was decerned to remove at Whitsunday in May although by custom he would have been allowed to retain possession of the arable land until his crops had been harvested (Dornoch Sheriff Court Records, SC9/7/). William subsequently decided to emigrate but in August Forbes wrote to Lord Reay's factor, Captain Mackay of Torboll, about the letting of the public house and William's predicament: "How is the Publick house to be settled it is so late of the year that Poor Wm Mackay I fear does not like going till Spring, could any thing be done for him you was always his friend \& now is the time" (Sutherland Papers, Dep.313/3369, Donald Forbes to Captain Mackay, 17 August 1806).

William Mackay managed to emigrate to PEI, as he and his family are recorded in the passenger list of the Elizabeth and Ann which left from Thurso in Caithness in August 1806 (Bumsted 1982, pp. 272-74; Campey 2001, pp. 127-29). William clearly envisaged that he should retain the status he had enjoyed in Sutherland. He raised a company of Colonial Highlanders of which he was captain (Mackay 1906, p. 299). In 1809, he acquired a substantial holding of over 600 acres from Cambridge which included the site of the abandoned settlement of New London. Mackay proceeded to enclose his land and in doing so blocked off a public roadway, thus denying a right of way for his neighbours to the "old burying place", the public ferry, and the harbour. A plan drawn up by the inspector of highways in 1811 to report on the dispute shows the site of Mackay's house. The government found for his neighbours and the road remained in place, although because Mackay did not allow passage to the burial place a new cemetery was established at the Yankee Hill Chapel (PEIGS 2000a, p. 3; Cousins 2016, p. 153; Stewart 1983). William died in 1826 and was buried in Sim's Field Cemetery with his wife and two of his sons. Despite a large family, only one son survived to have issue, John Mackay who married Sibla, daughter of Lieutenant John Mackenzie (see below). John immigrated to Australia in 1838 - the year he erected his parents' headstone at the cemetery (Mackay 1906, p. 299).

Also commemorated at Sim's Field is William Boyce Mackenzie, son of John Mackenzie, accidently drowned at Yankee Hill Point in 1840 aged 16 years. See Figure $2 b$. The clue to the possible identity of this person lies in the unusual first name, Boyce, which occurred within a particular branch of the Mackenzies from north west Sutherland.

Boyce Mackenzie, who died in Sutherland in 1877 aged 84, was a son of John Mackenzie at Badnabay and Janet Scobie, a daughter of Major John Scobie tacksman of Melness and Major of the Reay Fencibles. In the death certificate for Boyce, his father was described as a "stock farmer". Badnabay was a small farm on the large holding of George Mackay of Bighouse, centred on the lands of Scourie in the parish of Eddrachillis. Mackenzie was thus legally a subtenant, albeit clearly a tacksman rather than of small tenant status. This is confirmed by the fact that he had received a lieutenant's commission in the Reay Fencibles when it was raised in October 1794. He resigned the commission in February 1796 and died possibly later that year (Scobie 1914, p. 35). In 1800, his widow agreed to an increase in rent when Lord Reay obtained control of the lands held by Bighouse. However, she appears to have removed from Badnabay when Lord Reay's re-arrangement of the estate commenced the following year. The house of Badnabay was valued at $£ 30$ suggesting a very modest tacksman's house: the houses of the small tenants would have been worth approximately $£ 5$ while the houses of leading tacksmen on the Reay estate ranged from $£ 76$ for Keoldale to $£ 162$ Skerray and $£ 170$ Glendhu (Sutherland Papers, Dep.313/3326, Missives of Tacks and Estate Accounts).

After removing from Badnabay, John Mackenzie's widow married a Donald Mackenzie who appears to have been the "Mr Donald Mackenzie" who was tenant of Achriesgill at a rent of $£ 30$ (Reay Papers, GD84/2/84, Particular Rental of the Estate of Reay at Martins, 1808). As a minor tacksman, he was unable to retain possession when in 1815 there were 
further tenancy changes on the estate and Achriesgill was required for the resettlement of small tenants cleared from elsewhere. Donald Mackenzie and family, including some of his step-children, emigrated to Nova Scotia. In 1816, Donald Mackenzie and his stepson, Boyce Mackenzie, petitioned for land having come from Sutherland the previous year (RG20 Series A, Land Papers Deeds). Boyce returned to Scotland eventually becoming a large farmer on the Duke of Sutherland's estate. Some of the family, however, came to Lot 21 on PEI, which was not surprising as Donald Mackenzie's wife Janet was a cousin of William Mackay's wife. Sibla Mackenzie, a daughter of John Mackenzie and Janet Scobie who was mentioned in the petition, married William Mackay's sole surviving son John (noted above) and one of their sons was named Charles Boyce Mackay (Mackay 1906, p. 299). The William Boyce Mackenzie would appear, assuming the details on the headstone are correct and have been accurately transcribed, to be a son of John Mackenzie who was, in turn, a son of Donald Mackenzie and Janet Scobie.

\subsection{Emigrant Histories: Hector Falconer, South Granville Cemetery}

Hector Falconer is commemorated in the cemetery at South Granville where he was a leading man within the community. Hector died aged 85 in 1887 and his wife Mary Ross died aged 77 in 1883; unlike some of the other passengers on the Ellen who came to PEI in 1848, they are not described as natives of Sutherland. However, the existence of their headstone on PEI contrasts with the absence of any gravemakers commemorating their relatives who remained in the parish of Eddrachillis in Sutherland.

Hector was the son of James Falconer, a Caithness man who had been resident in Durness in north west Sutherland (where his eldest son was born). He had then moved south to the parish of Eddrachillis where he was recorded in 1810 as a weaver residing at Kylestrome. That place had by then been cleared for sheep, so we must assume that James was a subtenant with little security of tenure (Eddrachillis OPR). By 1819, he was sharing a holding in Scouriemore, then a very crowded small tenant township (Sutherland Papers, Dep.313/3439, Rental 1819). His son, James, appears the same year in a list of people in Scouriemore given meal by the estate (Sutherland Papers, Dep.313/3439, Account of 250 Bolls, Oatmeal). By 1822, James Falconer junior had become tenant of the holding along with his father-possibly as security (Sutherland Papers, Dep.313/3478, Rent Roll 1822). In January 1825, James and Hector Falconer signed an obligation to pay by 30 September a sum due from their father (Sutherland Papers, Dep.313/3380, Obligations, 1825). This is the first mention of Hector in the estate records; significantly both he and his brother were literate. The obligation was given the same year that the estate management began the process of implementing a tighter financial regime.

Further light on the family's circumstances comes from a list of boats drawn up later that year in which James Falconer senior is recorded as owning a 12-foot boat. However, this was not considered a "sufficient" fishing boat. A list of "sufficient" fishing boats, which ranged in size from 20 to 27 feet, included a single boat in Scouriemore with a length of 23 feet and crewed by James Falconer junior, Eric Mackenzie, John Falconer and Cathel Kerr. Such a boat would have been capable of following the herring shoals outwith the local lochs and indeed of taking part in the east coast herring season at Wick. James junior was 'Bound for his father', suggesting a direct link between fishing and the arrears due by James senior to the estate (Sutherland Papers, Dep.313/3364, List of Boats). The Falconers, however, were not solely dependent on the proceeds of fishing. Like most other households, they were also engaged in the manufacture of kelp during this period. Although living at Scouriemore, they were allocated the shores of Ardaloch and Maldy in Loch Glendhu along with William Morison piper. They were obliged to make three tons of kelp from their stretch of shore which was to be "divided according to the strength of the two families". The Falconers requested a supply of meal to enable them to undertake the arduous work (Sutherland Papers, Dep.313/3457, Sett of Edderachilles kelp \&c for 1826.).

A population list drawn up the following year lists James Falconer and James, his son, in the one household in Scouriemore. The Falconers' scanty livestock consisted of a 
cow and calf and two sheep (Sutherland Papers, Dep.313/3337, Population of Eddrachilles, 1826). There are no extant road commutation lists for Eddrachillis, but a collection of tickets for the militia ballot for all men between the ages of 18 and 45 includes James Falconer, tenant at Scouriemore (James junior), and Hector, John and Angus Falconer, all labourers there and, we may assume, living in the same household. Labourer was a common term for young men living with their parents and undertaking a variety of labouring work; differentiated from tenant, it was an indication as much of status as of employment (Dornoch Sheriff Court Records, SC9/87/104).

The increased intensity of estate management was to provide an opportunity for Hector Falconer to settle on the Island of Handa. Although Handa Island was one of the few inhabited islands off the northern mainland, it had been cleared by Lord Reay and given over to sheep in the early 1800s. The sheepfarmer had, like not a few others, gone bankrupt in the 1820 s because of the downturn in agricultural prices. This allowed the estate management to reconsider the best way of letting the island. Ralph Reed, the underfactor at Scourie, examined the island and thought it could take approximately 12 tenants, allowing $1 \frac{1}{2}$ acres to each. The whole island would be worth from $£ 40$ to $£ 45$ if let to "one Tenant to be occupied with thirtie Cattle, but as a Fishing Station I have no doubt It would be worth a good deal more, and from the Great command of sea ware it has Land in time might be taken in to render it capable of Keeping more tenants if thought necessary" (Sutherland Papers, Dep.313/3412).

Lord Reay decided that the island should be let to small tenants as crofters and in January 1828 Reed visited the island along with two local men to create lots (lotting was a common term at that period for laying out of crofts or individual holdings). The transformation of townships, with the arable land laid out as scattered strips under the runrig system, had commenced on the Reay estate as a whole as part of the new estate management approach. Reed and his advisers considered that the island would "make Ten tolarably good lots, which lots will run from the Sea upwards and that the houses should be placed on the Heath Land at the heads of the lots". Reed suspected that from the "variety of Soil we will scarcely be able to make all the lots of the Same Value". He had also begun to look for good fishermen to become tenants: "James Falkener Scoury more who has Five Sons all at home and all Fishers, I should think would be one of the properst for it" (Sutherland Papers, Dep.313/3424). Ten lots or crofts were laid off which ranged in size from 17 acres to just under three. The smaller ones probably contained a greater proportion of old arable land while the larger ones contained a higher percentage of grazing. The crofts were allocated by ballot with the stances for houses being pointed out by the underfactor. As might be expected from the large numbers of small tenants in the various townships, there was strong demand for these new holdings. The total rent of the island came to $£ 40$, which was an indication that small tenants or crofters could, in the right circumstances, pay as high a rent as a single tenant. A survey of small tenant houses in Eddrachillis states that the house in Scouriemore belonging to James Falconer senior and junior had a chimney although built with clay rather than lime mortar. Only four tenants on Handa Island had such a house, not including Hector Falconer. Some perspective is provided by the fact that only four out of 61 houses in the district were built with stone and lime mortar (Sutherland Papers, Dep.313/1054A).

A population list taken in 1839 revealed that there were 11 tenants or crofters on Handa Island along with one cottar. Most of the households were headed by a husband and wife apart from one widow. The total population amounted to 75 . All of the crofters had cattle: there were 58 head in all with the numbers, varying between three and eight per croft. Ten crofters had sheep, ranging from three to ten, giving a total for the island of 64 (Sutherland Papers, Dep.313/2684). There was a fair amount of emigration from the parish of Eddrachillis in the early 1840s, which was assisted by the Duke of Sutherland, and two households emigrated from Handa Island to Canada in 1841. The estate management took the opportunity to share the one tenant's croft between three of the other tenants. In 1846, the factor, Evander MacIver, stated that "The Handa Tenants are all good payers \& have a 
good Stock on the ground". Hector Falconer was said to have a "weak family", indicating that they were not able to assist him greatly on account of their age (Sutherland Papers, Dep.313/2797).

This favorable impression of the island was to change with the onset of the potato famine in 1846. The Sutherland estate management's main response to the famine was to provide relief work, particularly road building, and to encourage land improvement. Emigration from the district was also subsidized but this proved very costly, albeit the estate managers were convinced that the remaining population derived significant benefits from a "thinning" of the population. Four ships were funded by the Duke of Sutherland: two in 1847 and two in 1848. After the first two ships left in 1847, the estate management published several letters from the emigrants after their arrival in Canada; these letters served to encourage many more households to apply in 1848 .

The people on Handa Island were hit hard by the failure of their potato crop and applied for aid to emigrate. Four households left in 1847 and most of the remainder applied to leave the following year. The factor explained to the Duke's commissioner that a great number of tenants in his district had decided to emigrate, including all but two of the remaining tenants on the Island of Handa. He had summoned the remaining two to remove and awaited the Duke's instructions on whether to proceed. The people had "laboured under many disadvantages in the Island-no way of getting their children properly educated-difficulty in coming to Church-and often so stormy when they wanted the Doctor that they could not cross for him" (Sutherland Papers, Dep.313/1515). He was keen to see the island cleared of its people altogether and re-assured the Duke of Sutherland that the "settlement of Tenants in Handa is quite a recent business." While "Potatoes flourished they had plenty—but the land being a light sandy Soil it will not grow oats - and the last two seasons impoverished the people to such an extent that they Could not pay their Rents or Meal longer-and all but two resolved to emigrate- these flit to the Mainland and at Whitsunday there will be none there. The want of education for their Children was a great disadvantage. It is not thus twenty years since the Tenants were placed in it" (Sutherland Papers, D593/P/22/1/22 McIver to Duke of Sutherland, 25 April 1848). The estate commissioner, James Loch, was also convinced that neither Handa nor Shegra (see below) should have been cultivated. Neither was "calculated for the production of Corn. Their soil, climate, and exposure are all against its ripening. The introduction of the potatoe alone could have enabled the people who were settled there to maintain precarious existence" (Sutherland Papers, Dep.313/1365). The island was incorporated into Scourie sheep farm, tenanted by the factor who occupied it for forty years (MacIver 1905, pp. 215-16).

Hector Falconer was one of the passengers on the Ellen which sailed in 1848 from Loch Laxford in Sutherland to Pictou. Hector then travelled over to PEI from where he wrote to the estate factor in January 1849. His account, in the factor's view, was "not very flattering" and contrasted with the letters received from Canada West (Ontario) which were very encouraging (Sutherland Papers, D593/P/22/1/22, McIver to Duke of Sutherland, 9 February 1849.). Hector reported on the voyage which had taken four weeks and six days: "all the passengers with a very few exceptions were healthy-and in good spirits during the voyage." The captain had kept "the best order in the ship and stood by the regulations-on the other hand he was very attentive and kind to all the Passengers-and in particular to such as required Medical treatment".

Most of the passengers had remained in Nova Scotia but a few families had transferred to PEI-a move which had led to their being charged a head tax twice. Hector explained that he had "taken a farm here and I know I will to have contend with difficulties here as well as when there although something of another nature-I did not earn a shilling since I came to this Country. I commenced Cutting wood as soon as I took the farm in order to have some land clear next season - there is no public work going on in the place and consequently people Coming here destitute of means to support themselves the first Year till they get a Crop raised will find it very difficult coming through so that I could not 
Conscientiously encourage any man to come here-but as their mind leads them. Were it not that I had a little money coming here I would be an object with my family before I got a crop raised and I know before then I will not be master of one shilling - still to give proper justice to the Country if new comers had employment, it is a better Country for a poor man than that in the Course of some Years-there has been a failure in the Crop these three last Years, that left every thing dull in the place. Sir, I may confess I had a longing desire after the land of my Birth and for such as I was attachd. to in it" (Sutherland Papers, D593/P/22/1/22 H Falconer to E McIver, 15 January 1849.).

Hector obtained a 50-acre holding on the South Granville Road not far from the future site of the South Granville Presbyterian Church. By the terms of his lease, he was due for the first two years' rent at $3 \mathrm{~d}$ Sterling an acre, the next two years at $6 \mathrm{~d}$ an acre, one year at $9 \mathrm{~d}$ and then he was due a rent of 1 s per acre. His first rent was to be paid in May 1854. He paid $£ 2$ cash in 1857 and worked on a road; he and his son worked for 16 days on a survey; he paid some pork and cash in 1862, and oats in 1863 and 1864. Despite these payments, he was still left owing significant arrears (Cunard ledger: f.198). His immediate neighbour to the north was Cathel Keir who had also come from Island Handa (the name Kerr in Sutherland was rendered Keir on PEI). The entries in the Cunard ledger are indicative of the material poverty of the settlers in the South Granville district. This is confirmed by remarks in the 1861 agricultural census: "In some settlements, particularly in and around Mill Vale Road, many of the settlers are in very destitute circumstances, living on rented farms; and being poor when they came here, having scarcely any clearance, and many of them no other way of subsistence than by planting a little with the hoe, they scarcely gain a livelihood, although the people seem industrious. In general, the land is also very hilly" (Journal 1863, Appendix A).

\subsection{Emigrant Histories: The Gunn Families, South Granville Cemetery}

A headstone in the cemetery at South Granville commemorates in two panels "father" and "mother" McKenzie Gunn, who died in 1870 aged 73, and Margaret McKay who died in 1871 aged 74. The headstone states: "They emigrated from Sutherland Shire Scotland A.D.1848". Another headstone, also with two panels, records Benjamin Gunn who died in 1904 aged 83 and his wife Flora McKay who died in 1905 aged 82. They were "Natives of Sutherlandshire, Scot. Emigrated to this Island in 1848." See Figure 3a,b. A third headstone records William Gunn who died in 1891 aged 77 and his wife, Cristy Campbell, who died in 1913 aged 92. The headstone does not refer to his origins but a newspaper notice states that he was a native of Sutherlandshire and emigrated in 1848 (PEIGS 2001).

All three Gunns arrived at Pictou in Nova Scotia on the Ellen from Sutherland in 1848 and were part of the group which then continued on to PEI. McKenzie Gunn is said to have been uncle to the brothers, William and Benjamin (Gunn Family n.d.). According to the list of meal provided for passengers on the Ellen, McKenzie and William were both from the township of Shegra while Benjamin was from Rhimichie (Sutherland Papers, Dep.313/2739, List of meal \& bread for passengers per Ellen).

From entries in the estate rental books and the factor's notebook, it is clear that McKenzie was a tenant in Shegra and that William was in fact his brother. In 1845, William wrote to the factor that he had been twelve years in possession of land which he had paid for "tho not charged to own account". The factor noted of McKenzie, "His brother W[illia]m wants land, add a vacant lot to part of Mckenzies \& let him have it". The following year, William was given possession of a new holding formed by a share of McKenzie's holding, along with the holding possessed by a widow described as "old and frail" and with a daughter in receipt of parochial relief. As well as providing William with a substantial holding, it gave formal recognition to what had been an unofficial long-term arrangement between the two brothers whereby McKenzie had been the tenant named in the estate rental but William had been in possession of what had amounted to approximately half of McKenzie's holding. It is a reminder not to judge the size of a tenant's actual possession from the amount of rent he or she was paying. As the arable lands of the township 
were still under the runrig system rather than laid out in individual crofts, the holdings comprised strips of land in different parts of the township. In early 1847, the brothers had the following livestock: McKenzie had two cows and two followers and four sheep; William had two cows and a follower and 12 sheep. William's entry in the rental for the year 1847-1848 is annotated with the word "Emigrated" (Sutherland Papers, Dep.313/1354; Dep.313/2293-2294; Dep.313/2755(1); Dep.313/2797).

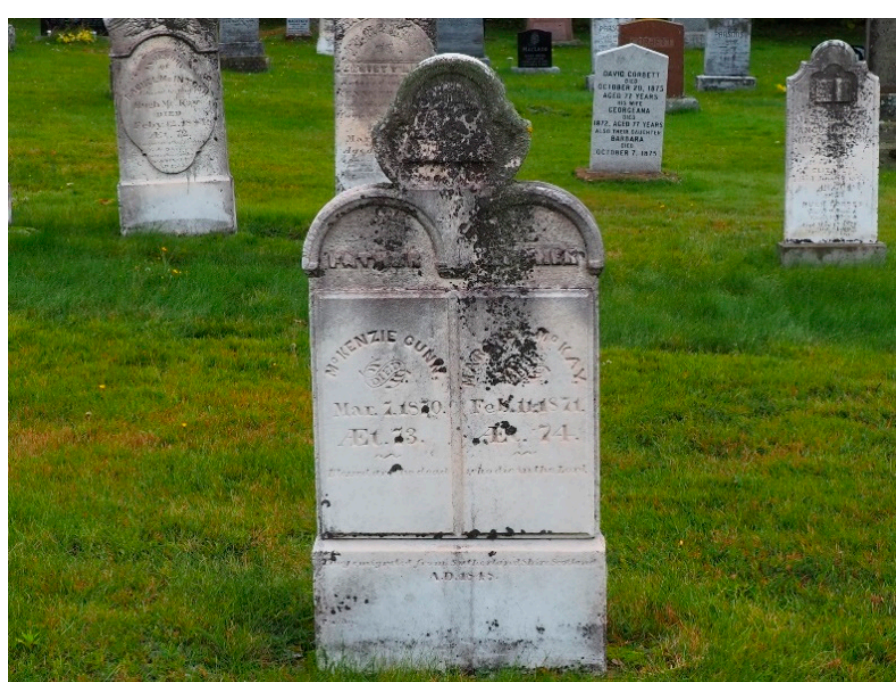

(a)

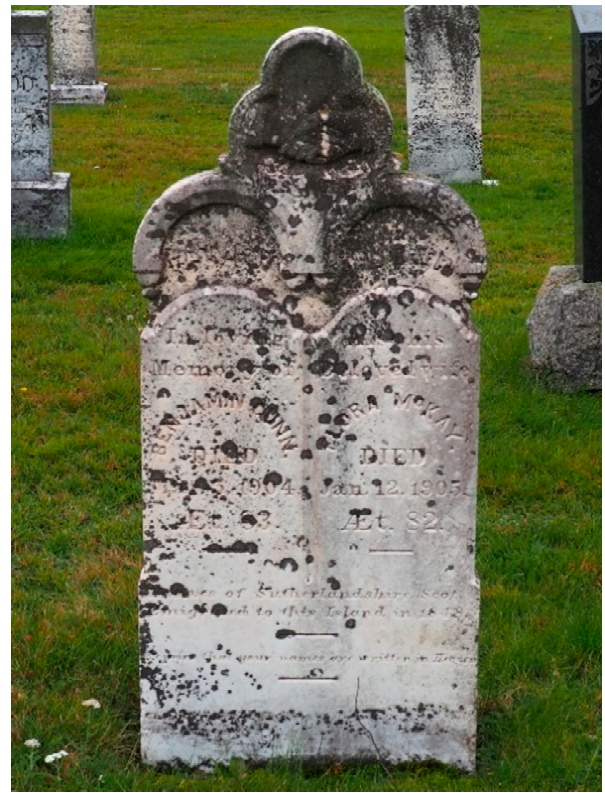

(b)

Figure 3. (a) Gravestone of McKenzie Gunn and Margaret McKay, South Granville Cemetery (2018); (b) gravestone of Benjamin Gunn and Flora McKay, South Granville Cemetery (2018).

William had married Chirsty (Cristy), daughter of Donald Campbell who was also a tenant in Shegra. Donald had been born on Island Choarie in the parish of Durness which had been cleared in the early 1800s. He was blind and, while he had a holding with some stock, he was in receipt of poor relief from 1845. When Shegra was cleared in 1848, he removed to Durine in the parish of Durness where he died in 1873 (Sutherland County Council, CS/6/6/18).

The official census for Shegra in 1841 includes the household of McKenzie Gunn and his family and also the household of John Gunn aged 72 tenant, Jean aged 69 and a William Gunn aged 25. In the factor's notebook for 1845, John Gunn is described as a cottar in Shegra "Old man-a weaver-2 old Daughters-no land-1 Cow" (Sutherland Papers, Dep.313/2797). William's birth is not recorded but on 21 January 1816 John Gunn weaver in Shegra had a son baptised with no recorded name.

McKenzie Gunn had become a tenant in Shegra in 1818; he is listed as one of the "new tenants'"to join several others already settled there (Sutherland Papers, Dep.313/3439, Rental Roll 1818). The township had been cleared in 1806 to form part of a small farm but had been made into a small tenant township again in 1815. It was placed in the hands of James Anderson, a fish merchant from Rispond in Durness, and most of the people were in fact his subtenants who were expected to fish for him. McKenzie married Meran Mackay in December 1823. In a sett or lease of the kelp shores on the estate in 1826, Mackenzie was given a half share of a stretch of shoreline; as with many of the other men of Shegra, he was not expected to manufacture kelp as he was "himself a fisher, his wife a Kelper" (Sutherland Papers, Dep.313/3457). A population list drawn up the same year cites McKenzie Gunn as a tenant in Shegra with a wife and two children. He possessed three cows and a follower and three sheep. John Gunn was listed as a weaver and householder in Shegra; he was 
thus a cottar with no land and indeed had no livestock (Sutherland Papers, Dep.313/3337, Population List of Mr Anderson's District.).

In 1830, McKenzie Gunn was a signatory to a petition requesting a reduction in rent. The township had been given up by Anderson, so the people were now direct tenants of the Marquis of Stafford. The arable lands of Shegra were "Situated in a Kind of low valley and consequently liable to be flooded by the stream of water which runs through them, which frequently occasions great loss to your Petitioners." They admitted that "the population is far greater than the place can support; that in consequence of the place not having been divided into lots the improvement is greatly impeded, and that by the failure of this year's fishing, your Petitioner's cannot pay the usual Rent" (Sutherland Papers, Dep.313/2411).

James Loch, commissioner for the Duke of Sutherland, reviewed the state of Shegra in 1835 after a number of requests had been made by the tenants for the arable land to be re-arranged into crofts. The amount of arable land had been "made small, in order that they [the tenants] might become Fishermen only, and so that they might not depend upon their Lots for maintenance." While the local fishing had not succeeded, elsewhere there were opportunities to extend the area of cultivation and to earn income through the herring fishery on the east coast. At Shegra, however, "the old arable land was most limited in extent; the adjoining was Sandy links, and Should never have been broke out of Grass. It hardly pays for Cultivation, and is rapidly blowing away." The tenants were in "reduced Circumstances" and Loch saw no advantage in the township being made into crofts. There were no vacant holdings in the district. However, as the people had been "shewing a tendency to go to Canada it is a matter well worthy of Consideration whether a Slight encouragement on the part of the Landlord, Should not be afforded, to enable them to carry their Intention into effect" (Loch Papers, GD 268/248).

Benjamin Gunn emigrated from Rhimichie. In the census of 1841, Benjamin was living with his parents, Donald Gunn and Barbara Morrison. In 1845, the factor considered Donald to be a "Good Tenant-Good Stock-one son married in House-4 Daughters"; the entry was later annotated to read "The best lot-Lots of cairns of Stones-push him to improve" (Sutherland Papers, Dep.313/2797). The township was part of the district considered unsuitable for sheep and had been resettled in 1831. Previously, Donald Gunn had been a tenant in West Badcall or Badcall Scourie (to distinguish it from Badcall Inchard). Most of his children had been born in Badcall: Benjamin was the eldest having been born in 1820. In 1826, Donald Gunn was one of ten tenants and had three cows and three sheep (Sutherland Papers, Dep.313/3337, Population of Eddrachilles, 1826). He had a 12-foot boat but while he only had a half 'lot' or share in the township (perhaps sharing with his father), the estate official considered that he could manufacture a full share of kelp (Sutherland Papers, Dep.313/3364).

Three tenants had emigrated from Rhimichie in 1836, but replacements had been brought into the township. Two tenants had emigrated in 1847 to Pictou and two tenants followed the next year. In December 1850, the factor reported to the Sutherland estate commissioner that the remaining five tenants of Rhimichie were "all due two Rents-and not one penny paid." He proposed that they should all be removed and accommodated with vacant possessions throughout the parish. It was "better to have the old people on the Poors Roll as Paupers-than have them as Tenants not paying Rents-nothing is more infectious than non-payment of Rent-it spreads like wildfire when once begun" (Sutherland Papers, Dep.313/1516). The following year, the five tenants were found vacant crofts in the district and the township was converted into a small farm.

Benjamin Gunn, who had not been a tenant, had emigrated with his family but his father, Donald, had not accompanied him. Instead, Donald Gunn had moved to Achliness. His wife died in 1855, and he and an unmarried daughter later moved to Portnacon in the parish of Durness to be near a son and a married daughter. One other daughter was married in Orkney and his son, Benjamin, was said to be on Prince Edward Island. He had a free house and a small piece of land for potatoes. He died in 1870 (Sutherland County Council, CS/6/6/18). While it might be tempting to suggest that Donald was a brother to 
McKenzie and William Gunn, it should be noted that there was a Benjamin Gunn living in Badcall in 1808 who was still there in 1826 (Reay Papers, GD84/2/84; Sutherland Papers, Dep.313/3337, Population of Eddrachilles, 1826), and that Widow Benjamin Gunn was a tenant in Rhimichie in 1839 (Sutherland Papers, Dep.313/2684). Benjamin Gunn who emigrated to PEI was probably named after his grandfather, as might be expected from traditional naming patterns. He may well have been related to McKenzie and William Gunn but at what remove is not known.

\section{Conclusions}

The recording of personal details on gravemarkers was a matter of careful choice and there is very little evidence on personal motivation and why some immigrants from Sutherland to PEI chose to specify their place of birth and, in some instances, the year they sailed. However, the desire for some emigrants and their descendants to do so has given us an important source of information both as to the chronology and broadscale geographical origins of an emigrant community. The gravemarkers give only a partially accurate picture for the precise origins of settlers within Sutherland. While a majority of the pioneer settlers appear to have come from Durness, by the mid-1830s significant numbers were coming from the Eddrachillis, and a majority of those who came during the Famine years were from Eddrachillis.

It is important to bear in mind that there were individuals who chose to make their own way and settle in areas not renowned for their connections with Sutherland or the Scottish Highlands (even if they took advantage of Scottish networks and cultural associations and maintained links with the homeland). However, Lot 21 of Prince Edward Island is one of a number of areas in Canada which contained a strong concentration of Sutherland settlers (even if they were not necessarily wholly dominant). Other areas with a similar concentration included: the townships of Zorra in Oxford County, Ontario; St. Ann's in Cape Breton; and Earltown in Colchester County, Nova Scotia. For potential emigrants, there were choices to be made as to destination, and the fact that some emigrants from north west Sutherland continued to choose a particular area within PEI over a 40-year period speaks not only to the strength of 'chain' migration but also to the maintenance of an interaction with the homeland for which we have little other evidence.

The concept of enforced exile from the homeland is firmly entrenched in the minds of many descendants. However, as passenger lists compiled by the estate managers and estate accounts testify, those who were cleared before they emigrated were in the minority. Moreover, there was not any landlord-organized 'compulsory emigration' for the people of north west Sutherland. That said, there were undoubtedly propellant forces just as there were forces which attracted emigrants to PEI and other destinations. Even for those who were cleared, and the emigrant histories include several examples, the decision to emigrate did, on balance, involve a degree of choice. As Harper has stated, "emigrants could be both passive victims and active agents of their own destiny" (Harper 2017, p. 64).

This scenario is apparent from the story of a minor tacksmen such as William Mackay. While some leading tacksmen transferred to the new order and became sheep farmers, William Mackay was an example of those who lost out to those with more capital in the tenurial rearrangement of the Reay estate. Men in his position faced a number of choices: they could become leading small tenants (an almost certain decline in status); they could look for a tenancy elsewhere; or, depending on their means, they could retire to a town.

For many in north west Sutherland during the first half of the 19th century, there were longer-term forces of dislocation initially created by clearance and resettlement, which had led to congestion, land hunger and vulnerability. The role of the landlord could be crucial not only in setting such forces in motion but also providing a route of escape. There is evidence that the earlier emigrants were not destitute. Nevertheless, there is no doubt of the general poverty of the emigrants from north west Sutherland in the 1840s, particularly those who formed the community of Prince Edward Island's South Granville. 
Funding: This research received no external funding.

Acknowledgments: The author gratefully acknowledges the assistance of Carol MacLellan of PEI and Barry MacKenzie of St. Francis Xavier University. This paper commemorates the work of family historian Angi Lamb who died July 2020.

Conflicts of Interest: The author declares no conflict of interest.

\section{References}

\section{Archival Sources}

Census Returns for Parish of Eddrachillis 1841.

Eddrachillis OPR: National Records of Scotland, Old Parish Register for Eddrachillis, Baptism of William Falconer, 11 March 1810.

Forbes 1806a: National Library of Scotland, Sutherland Papers, Dep.313/3369, Donald Forbes to Lord Reay, 15 January 1806.

Forbes 1806b: National Library of Scotland, Sutherland Papers, Dep.313/3369, Donald Forbes to Captain Mackay, 17 August 1806.

Highland Archive, Inverness, Scotland, Sutherland County Council, CS/6/6/18, General Register of Poor for Eddrachillis.

National Library of Scotland, Sutherland Papers, Dep.313/1054A, A List of Cottages in Edds.

National Library of Scotland, Sutherland Papers, Dep.313/1354, W Gunn to E McIver, 20 November 1845.

National Library of Scotland, Sutherland Papers, Dep.313/3457, Sett of Edderachilles kelp \&c for 1826.

National Library of Scotland, Sutherland Papers, Dep.313/3326, Missives of Tacks and Estate Accounts.

National Library of Scotland, Sutherland Papers, Dep.313/2755(1), List of Small Tenants in Edds. with their Stock, 1847.

National Library of Scotland, Sutherland Papers, Dep.313/2739, List of meal \& bread for passengers per Ellen.

National Library of Scotland, Sutherland Papers, Dep.313/3364, List of Boats \&c, Edderachilles Parish.

National Library of Scotland, Sutherland Papers, Dep.313/1365, J. Loch to E. McIver, 16 May 1848.

National Library of Scotland, Sutherland Papers, Dep.313/1515, pp.948-951, E. McIver to J. Loch, 21 March 1848.

National Library of Scotland, Sutherland Papers, Dep.313/1516, E. McIver to J. Loch, 31 December 1850.

National Library of Scotland, Sutherland Papers, Dep.313/3439, Account of 250 Bolls, Oatmeal Distributed as follows in Parish of Eddrachiles, Durness and Tongue in June 1819.

National Records of Scotland, Dornoch Sheriff Court Records, SC9/87/104, Militia tickets for parishes of Assynt, Lairg and Eddrachillis, 1826.

National Library of Scotland, Sutherland Papers, Dep.313/2797 [Factor's notebook c1845].

National Library of Scotland, Sutherland Papers, Dep.313/3380, Obligations, 1825 [Parish of Eddrachillis].

National Library of Scotland, Sutherland Papers, Dep.313/2411, Petition by Shegra Tenantry 1830.

National Library of Scotland, Sutherland Papers, Dep.313/3337, Population of Eddrachilles, 1826.

National Library of Scotland, Sutherland Papers, Dep.313/3337, Population List of Mr Anderson's District.

National Library of Scotland, Sutherland Papers, Dep.313/2684, List Population of the Tenentry in the parish of Edds.

National Library of Scotland, Sutherland Papers, Dep.313/3412, R. Reed to J. Horsburgh, 6 February 1827.

National Library of Scotland, Sutherland Papers, Dep.313/3424, R. Reed to J. Horsburgh, 15 January 1828.

National Records of Scotland, Dornoch Sheriff Court Records, SC9/7/, Processes Summons, Rt. Honble Lord Reay Kenneth Mackay Esqr his Factor agt., Tenants, 1806.

National Records of Scotland, Reay Papers, GD84/2/84.

National Library of Scotland, Sutherland Papers, Dep.313/3326, Particular Rental of the Estate of Reay for the Year, and Martinmass 1797.

National Records of Scotland, Reay Papers, GD84/2/84, Particular Rental of the Estate of Reay at Martins, 1808.

National Library of Scotland, Sutherland Papers, Dep.313/3439, Rental Roll of Small Tenants as to be collected by Lord Reay's Factor at Martinmas, 1818.

National Library of Scotland, Sutherland Papers, Dep.313/3439, Rental Roll of the Small Tenants on the Estate of Reay at Marts, 1819.

National Library of Scotland, Sutherland Papers, Dep.313/3478, Rent Roll of Small Tenants on Reay Estate Martinmas, 1822.

National Library of Scotland, Sutherland Papers, Dep.313/2293-2294 Rentals 1845-1847.

National Records of Scotland, Loch Papers, GD 268/248, Report of the Condition of the Estates of Sutherland and the Reay Country made during Mr Loch's Tour and Inspection \&c, 1835.

National Library of Scotland, Sutherland Papers, Dep.313/2062, Sundry Emigrants, 11 June 1847.

National Library of Scotland, Sutherland Papers, Dep.313/2066, Receipts, 24 June 1848, Bonded Stores per Greenock.

Provincial Archives of Nova Scotia, RG20 Series A, Land Papers Deeds, vol 68 Petition of Donald and Boyce Mackenzies.

Public Archives and Records Office of Prince Edward Island, RG15, Cunard Rent Book 1841-1851.

Public Archives and Records Office of Prince Edward Island, RG15/S/2, volume 18 Cunard Estate Ledger B.

Public Archives and Records Office of Prince Edward Island, MacLennan Collection, Acc. 4679, History of South Granville Presbyterian Church.

Staffordshire Record Office, England, Sutherland Papers, D593/P/22/1/22 copy H Falconer to E McIver, 15 January 1849.

Staffordshire Record Office, England, Sutherland Papers, D593/P/22/1/22, E. McIver to Duke of Sutherland, 25 April 1848.

Staffordshire Record Office, England, Sutherland Papers, D593/P/22/1/22, E. McIver to Duke of Sutherland, 9 February 1849. 


\section{Published Sources}

Adams, Ian, and Meredyth Somerville. 1993. Cargoes of Despair and Hope: Scottish Emigration to North America 1603-1803. Edinburgh: John Donald.

Bangor-Jones, Malcolm. 2000. From Clanship to Crofting: Landownership, Economy and the Church in the Province of Strathnaver. In The Province of Strathnaver. Edited by John Baldwin. Edinburgh: The Scottish Society for Northern Studies.

Bumsted, J. M. 1978a. Highland Emigration to the Island of St. John and the Scottish Catholic Church, 1769-1774. Dalhousie Review 58: 511-27.

Bumsted, J.M. 1978b. Lord Selkirk of Prince Edward Island. The Island Magazine 5: 3-8.

Bumsted, J. M. 1978c. Settlement by Chance: Lord Selkirk and Prince Edward Island. Canadian Historical Review 59: 170-88. [CrossRef]

Bumsted, J. M. 1979. Captain John MacDonald and the Island. The Island Magazine 6: 15-20.

Bumsted, J. M. 1982. The People's Clearance: Highland Emigration to British North America 1770-1815. Edinburgh: Edinburgh University Press.

Bumsted, J. M. 1987. Land, Settlement, and Politics on Eighteenth-Century Prince Edward Island. Kingston and Montreal: McGill-Queen's University Press.

Campey, Lucille H. 2001. "A Very Fine Class of Immigrants": Prince Edward Island's Scottish Pioneers, 1770-1850. Toronto: Natural Heritage Books.

Cousins, John. 2016. New London: The Lost Dream: The Quaker Settlement on P.E.I.'s North Shore, 1773-1795. Charlottetown: Island Studies Press.

Cowper, A. S., and I. Ross. 1989. Pre-1855 Tombstone Inscriptions in Sutherland Burial Grounds. Edinburgh: Scottish Genealogy Society.

Dale, Janet. 1976. P.E.I. Passenger Lists: A Genealogical Myth Struck Down. The Island Magazine 1: 34-39.

Dale, Janet. 1977a. P.E.I. Passenger Lists: Part Two. The Island Magazine 2: 39-42.

Dale, Janet. 1977b. P.E.I. Passenger Lists: Part Three. The Island Magazine 3: 31-37.

Devine, T. M. 2011. To the Ends of the Earth: Scotland's Global Diaspora. London: Allen Lane.

Evans, Nicholas J., and Angela McCarthy, eds. 2020. Death in the Diaspora: British and Irish Gravestones. Edinburgh: Edinburgh University Press.

Fraser, Douglas. 1989. More Elusive Emigrants. The Island Magazine 26: 35-40.

Fraser, Douglas. 1990. More Elusive Emigrants: Part Two. The Island Magazine 27: 38-41.

Gunn Family. n.d. Pleasant Valley Community History and Stories. Available online: http:/ /www.pleasantvalleypei.ca/ (accessed on 23 August 2020).

Harper, Marjory. 2003. Adventurers and Exiles: The Great Scottish Exodus. London: Profile Books.

Harper, Marjory. 2017. "Quite destitute and ... very desirous of going to North America": The Roots and Repercussions of Emigration from Sutherland and Caithness. Northern Scotland new series 8: 49-67. [CrossRef]

Hornsby, Stephen. 1988. Migration and Settlement: The Scots of Cape Breton. In Geographical Perspectives on the Maritime Provinces. Edited by Douglas Day. Halifax: Saint Mary's University.

Hunter, James. 2015. Set Adrift Upon the World: The Sutherland Clearances. Edinburgh: Birlinn.

Jones, Orlo, and Douglas Fraser. 1984. Those Elusive Immigrants. The Island Magazine 16: 36-41.

Jones, Orlo, and Douglas Fraser. 1985a. Those Elusive Immigrants: Part Two. The Island Magazine 17: 32-37.

Jones, Orlo, and Douglas Fraser. 1985b. Those Elusive Immigrants: Part Three. The Island Magazine 18: 29-35.

Journal. 1863. Journal of the House of Assembly of Prince Edward Island for 1863. Charlottetown: G. T. Haszard.

Kennedy, Michael. 1995. Is leis an Tighearna an Talamh agus an Lan (The Earth and all that it Contains Belongs to God): The Scottish Gaelic Settlement History of Prince Edward Island. Ph.D. thesis, University of Edinburgh, Edinburgh, UK. Available online: https: / / era.ed.ac.uk/handle/1842/20603 (accessed on 26 January 2021).

Kennedy, Michael. 2003. "The People are Leaving": Highland Emigration to Prince Edward Island. The Island Magazine 53: 31-41.

Lamb, Angi. 2014. Durness Marriages from 1765 to 1875. Unpublished.

Little, J. I. 1991. Crofters and Habitants: Settlers Society, Economy, and Culture in a Quebec Township 1848-1881. Montreal and Kingston: McGill-Queen's University Press.

MacIver, Evander. 1905. Memoirs of a Highland Gentleman. Edinburgh: Constable.

Mackay, A. 1906. The Book of Mackay. Edinburgh: Norman MacLeod.

McLean, Marianne. 1991. The People of Glengarry: Highlanders in Transition, 1745-1820. Montreal and Kingston: McGill-Queen's University Press.

O'Grady, Brendan. 2004. Exiles and Islanders: The Irish Settlers of Prince Edward Island. Montreal and Kingston: McGill-Queen's University Press.

PEIGS (P.E.I. Genealogical Society). 2000a. Cemetery Transcript Yankee Hill Cemetery, French River, Lot 21-8. Charlottetown: PEIGS.

PEIGS (P.E.I. Genealogical Society). 2000b. Cemetery Transcript Simm's Field Cemetery, French River, Lot 21-10. Charlottetown: PEIGS.

PEIGS (P.E.I. Genealogical Society). 2000c. Cemetery Transcript Presbyterian Church Cemetery, South Granville, Lot 21-5. Charlottetown: PEIGS.

PEIGS (P.E.I. Genealogical Society). 2000d. Cemetery Transcript Geddie Memorial Church Cemetery. New London, Lot 21-2. Charlottetown: PEIGS.

PEIGS (P.E.I. Genealogical Society). 2001. From Scotland to Prince Edward Island. Charlottetown: PEIGS. 
PEIGS (P.E.I. Genealogical Society). 2011. Cemetery Transcript New London Peoples Cemetery, New London, Lot 21-3. Charlottetown: PEIGS. Pleasant Valley History Committee. 2019. Pleasant Valley, Prince Edward Island. Pleasant Valley: Pleasant Valley History Committee. Richards, Eric. 1985. A History of the Highland Clearances: Volume 2: Emigration, Protest, Reasons. London: Croom Helm.

Richards, Eric. 2011. Highland Emigration in the Age of Malthus: Scourie, 1841-1855. Northern Scotland new series 2: 60-82. [CrossRef]

Richards, Eric. 2018. The Genesis of International Mass Migration: The British Case, 1750-1900. Manchester: Manchester University Press. Scobie, I. H. Mackay. 1914. An Old Highland Fencible Corps. Edinburgh: William Blackwood.

Sheets, John W. 2004. The Americans, the Earl of Selkirk and Colonsay's 1806 emigrants to Prince Edward Island. Scottish Local History 61: 11-21.

Snell, K. D. M. 2009. Parish and Belonging: Community, Identity and Welfare in England and Wales, 1700-1950. Cambridge: Cambridge University Press.

Stanley-Blackwell, Laurie, and Michael Linkletter. 2018. Inscribing Ethnicity: A Preliminary Analysis of Gaelic Headstone Inscriptions in Eastern Nova Scotia and Cape Breton. Genealogy 2: 29. [CrossRef]

Stanley-Blackwell, Laurie, and Michael Linkletter. 2020. Looking for Thistles in Stone Gardens: The Cemeteries of Nova Scotia's Scottish Immigrants. In Death in the Diaspora: British and Irish Gravestones. Edited by Nicholas J. Evans and Angela McCarthy. Edinburgh: Edinburgh University Press.

Stewart, Chester B. 1983. Roadblock 1810. The Island Magazine 13: 14-18.

Trask, Deborah. 1978. Life How Short, Eternity How Long: Gravestone Carving and Carvers in Nova Scotia. Halifax: The Nova Scotia Museum. 